University at Buffalo School of Law

Digital Commons @ University at Buffalo School of Law

Journal Articles

Faculty Scholarship

2015

\title{
Lords and Order: Credible Rulers and State Failure
}

Matthew Dimick

University at Buffalo School of Law

Follow this and additional works at: https://digitalcommons.law.buffalo.edu/journal_articles

Part of the History Commons, Law Commons, and the Political Science Commons

\section{Recommended Citation}

Matthew Dimick, Lords and Order: Credible Rulers and State Failure, 27 Rationality \& Soc'y 161 (2015).

Available at: https://digitalcommons.law.buffalo.edu/journal_articles/86

Matthew Dimick, Lords and Order: Credible Rulers and State Failure, Rationality and Society (27:2) pp. 161-194.

Copyright (C) 2015 SAGE Publications. Reprinted by permission of SAGE Publications. Available at 10.1177/ 1043463115576137.

\section{IN COPYRIGHT}

This Article is brought to you for free and open access by the Faculty Scholarship at Digital Commons @ University at Buffalo School of Law. It has been accepted for inclusion in Journal Articles by an authorized administrator of Digital Commons @ University at Buffalo School of Law. For more information, please contact lawscholar@buffalo.edu. 


\title{
LORDS AND ORDER: CREDIBLE RULERS AND THE CAUSES OF STATE FAILURE*
}

\author{
Matthew Dimick
}

February 27, 2009

*I wish to thank David Crouch, Scott Gehlbach, Daniel Klerman, Pablo Mitnik, and Erik Olin Wright for comments and suggestions. A special thanks goes to Ivan Ermakoff for providing detailed comments with every successive draft. A very special thanks goes to James Montgomery for insightful assistance in constructing the model and for invaluable help in programming simulations. I also wish to acknowledge the source of the paper's title from Chapter 9 of Crouch (2000) which in turn owes its inspiration to Barthélemy (1990). Direct correspondence to Matthew Dimick, Department of Sociology, University of Wisconsin-Madison, 8128 Sewell Social Science Bldg., 1180 Observatory Dr., Madison, Wisconsin 53706-1393. E-mail: mdimick@ssc.wisc.edu 


\title{
Lords and Order: Credible Rulers and the Causes of State Failure
}

\begin{abstract}
Why do states fail? Why do failed states persist without collapsing into complete anarchy? This paper argues that given insurgency or weakened state capacity, rulers may find it best, paradoxically, to reduce the amount of political good it provides as a means of sustaining some amount of their rule. Moreover, although the consequence is political fragmentation and increasing levels of violence, this is not inconsistent with the continuation of attenuated central governance. To evaluate this argument, I select the case of King Stephen's reign in medieval England. Although far removed historically from contemporary cases of state failure, the reign of King Stephen exhibits just those characteristics of modern, failed states: insurgency, civil war, territorial fragmentation, increasing disorder and violence (even between adherents to the same side of the civil conflict), and yet the persistence of some amount of centralized rule.
\end{abstract}

Word count: 11754 


\section{Introduction}

The problem of social and political order has long attracted sociologists, political theorists, and philosophers, often as an abstract normative concept. However, within the last few decades the increasing appearance of fragile states in places as diverse as Bosnia, Colombia, and the Congo has demonstrated that political order is a pressing and practical problem (Bates, 2008, 5). Such "weak" or "failed" states exhibit a series of distressing characteristics. First, such states undergo fragmentation and loss of territoriality (Rotberg, 2003, 5-6). Second, they experience increasing levels of disorder and violence (ibid., p. 6). Third, more interesting, and despite the previous weaknesses, some semblance or degree of central rule persists. Thus, the existence of the state is not an either/or proposition, but a "continuum" (Reno, 1998, 3). Compared to ideal-typical "strong" states there are not just weak states, but more unstable "failed" states and even "collapsed" states where central governance has completely disintegrated (Rotberg, 2003). These features of failed states raise several questions: Why do states fail? Why do failed states persist without completely collapsing (Jackson and Rosberg, 1982; Rotberg, 2003, 11)?

Much attention has been directed toward structural factors to explain weak or failed states. For example, ethnic divisions and tensions (Fearon and Laitin, 2003); decline of international aid following the end of the Cold War (Cooper, 2002; Reno, 1997); the unintended effects of neoliberalization (Reno, 1998); a burgeoning "conflict trade" in diamonds, timber, or other primary commodities (Collier and Hoeffler, 2004; Cooper, 2002); and the proliferation of arms dealers and private military firms (Klare, 2004; Musah, 2002) have all been identified and examined as proximate causes of state failure. Without discounting those factors, this paper, along with others,

focuses on the decision problems of rulers facing such constraints. For example, Bates $(2008,7)$ stresses how rulers' "penchant for predation" provokes insurgency and leads to political disorder. In another ruler-centric account, Reno (1998) argues, "Paradoxically, rulers of the institutionally weakest states ... are the most consistent and thorough in destroying remaining formal state institutions" (p. 7). Thus, rulers promote the transition to "fragmented sovereignty" (Reno, 1997, 493) by destroying state bureaucracies as a means of denying resources and sources of patronage 
to rivals (Reno, 1998, 19).

This paper highlights another paradox of ruler's behavior and its implications for the logic of political disorder. It claims that given a crisis, rulers may find it best to reduce the amount of political good they provide as a means of sustaining some amount of their rule. The argument is that rulers who provide protection in exchange for taxes (or, more broadly, the right to exercise political authority) must be able to credibly promise that they will deliver such protection to their clients. Political crises, such as insurgency or weakened state capacity, jeopardize that credibility. To prevent clients from completely abandoning the state, the ruler can lower the costs of protection by reducing the amount of protection it promises to provide-and thereby restore its credibility. Yet a lower amount of protection increases the incidence of conflict between clients. Correlatively, the ruler must also reduce the tax it charges to its clients to keep them participating in the regime. State failure can therefore result not only from raw predation, but attempts to sustain the credibility of the ruler's rule. Further, the weakening of central government organization-via the reduction in centrally-provided security-may not only be a way of denying resources to rivals, but also a way of maintaining some loyalty from local power holders. Moreover, although the consequence is political fragmentation and increasing levels of violence, this is not inconsistent with the continuation of an attenuated state, that is, with rulers continuing to provide some protection and recipients of protection continuing to pay for it (cf., Bates, Greif and Singh, 2002, 612).

The logic of this argument is developed in a formal model that follows in the path of those developed by Dixit (2003, 2004) and Milgrom, North and Weingast (1990). In these models, citizens or clients engage in bilateral exchange or trading opportunities and may call on the services of a judge, patron, or protector when a partner reneges. The patron provides such services in exchange for a fee or tax, while the patron's fairness and credibility are based on its reputation. The model presented in this paper is most similar to the one analyzed in Bates, Greif and Singh (2002), where, rather than trade or exchange, actors and clients of the patron face one another in potential, bilateral conflict. As in that contribution, conflict is modeled along the lines of Grossman and Kim (1995), Hirshleifer (1989, 2000), and Skaperdas (1992, 1996). The model presented here advances 
on the one in Bates, Greif and Singh (2002) in three ways. First, conflict between actors (warlords, warring groups, etc.) is probabilistic. Second, the probability of conflict varies with the amount of protection the ruler provides-less protection results in a higher probability of conflict. And third, the varying probability of conflict yields a notion of political order that is not dichotomous. For appropriate parameter values, there is an equilibrium where actors pay no taxes and the patron provides no protection. In another equilibrium, actors pay taxes, the ruler provides protection, and the chance of conflict is zero. Between these two, there are several equilibria with varying conflict-occurrence probabilities in which clients pay taxes and the ruler provides some amount of protection. The model can therefore allow for the emergence of several degrees of "stateness."

In addition to providing a model, the paper also pursues an empirical analysis. Others have described the adopted method as an "analytic narrative" (Bates et al., 1998). Such an approach attempts to combine the formal reasoning and logic of deductive models with the detailed, in-depth knowledge of case studies. On the one hand, a formal model makes explicit the logic of the theory and generates testable claims. On the other, intensive investigation a single case allows a better view of the causal mechanisms and pathways between independent and dependent variables as it also helps to discipline the theory (George and Bennett, 2005, 28-30, 32-33). Such an approach has been used throughout the social science disciplines, for example, in economics (Greif, 2006), political science (Bates et al., 1998), and sociology (Ermakoff, 2008).

The empirical case I select is the reign of King Stephen in medieval England. For its time, medieval England was notable for its highly centralized state (Hollister and Baldwin, 1978; Strayer, 1970). However, a civil war began during Stephen's reign, precipitated by his cousin Matilda's bellicose challenge to his rule. Medieval, feudal regimes have often been recognized as additional cases of weak states (Bates, Greif and Singh, 2002, 601-02, 612-13), though they have not been systematically examined with problems of contemporary failed states in mind. Indeed, the reign of King Stephen exhibits just those characteristics of modern, failed states: insurgency, civil war, territorial fragmentation, increasing disorder and violence (even between adherents to the same side of the civil conflict), and yet the persistence of some amount of centralized rule. 
In the next section, the model will be presented and its equilibria analyzed. Following the presentation of the model, it will be evaluated against the political events of the reign of King Stephen of England. A conclusion will follow the empirical analysis.

\section{Model and Equilibrium}

In this section, I present a model of the state, where a ruler provides protection in exchange for a payment of tax or rent. The first subsection analyzes a simple game of conflict between actors without a state. The primary goal of this section will be to establish a baseline model of conflict for the subsequent section. In the subsequent subsection, we will expand upon this baseline model by including a ruler or protector and establish the key propositions of the paper. Before delving into the technicalities of the model, however, let me first provide a brief overview in natural language.

With the model, I seek to demonstrate that when faced with worsening chances of survival (e.g., because of an insurgency) or a weakening of state capacity, a ruler can avoid a complete collapse of the state by reducing the amount of protection it provides to clients (e.g., citizens, clans, or warlords). The key logic underlying this is the ruler's desire to maintain credibility. When survival chances decrease or state capacity weakens, rulers become tempted to take their clients' rent payments and then renege on their protection promises. Anticipating this, clients will withhold their payments and withdraw from the state. If this happens, the state collapses and the ruler gets nothing. To prevent this, patrons can reduce the amount of protection they provide, which lowers the cost of providing protection and then in turn makes the ruler's promises once again credible.

But reducing protection, though it maintains the state, weakens it. One consequence of reducing the amount of protection the ruler provides is that the probability of conflict between clients increases. And as a result of the increased chances of conflict, which is costly to clients, the patron must also reduce the amount of tax she charges in order to keep the clients paying any tax at all. Hence, as both the benefits in taxes and burdens in protection costs decrease, the state begins to 
fragment: clients provide more for their own protection and less, in taxes, to support the state. Nevertheless, the state persists. How much protection and taxes are reduced, and how much conflict chances increase depends on how much the ruler needs to reduce protection costs in order to maintain credibility. Thus the state can continue to exist, that is, clients continue to pay the protection rent and the patron continues to provide some protection, even in the midst of positive levels of conflict and disorder.

\subsection{Conflict without a State}

We first analyze a game that has a "state of nature" condition where actors may attack other actors and must defend themselves from attacks through self-protection. I will call this the "conflict game." Let there be a set of actors $N=\{1,2\} .{ }^{1}$ Each actor has an endowment of size $R$. In each period, actors allocate their endowments either to consumption $c_{i} \geqslant 0$ or to arming $k_{i} \geqslant 0$, subject to the endowment constraint, $k_{i}+c_{i}=R$. Payoffs are determined by consumption, and since $c_{i}=R-k_{i}$ we will write payoffs $V_{i}\left(k_{i}, k_{j}\right)$ as a function of $R$ and the choice variable $k_{i}$. Actors live for one period, after which they "die" and are replaced by a new actor. The primary motivation for this is as a simplifying assumption (see, e.g., Kreps, 1990). In any case, as Bates, Greif and Singh (2002, 608-09) argue, an equilibrium justified by an appeal to the Folk Theorem where there is neither arming nor conflict in the absence of the state is likely to be fragile.

Following this allocation decision, each actor must decide whether to initiate a conflict or not. If neither actor initiates a conflict, an actor consumes the amount of resource left after arming. If an actor initiates a conflict, the remaining resources of both actors $\left(2 R-k_{i}-k_{j}\right)$ are subject to seizure and are divided according to the amount each actor allocates to arming $\frac{k_{i}}{k_{i}+k_{j}} \cdot{ }^{2} \mathrm{I}$ assume that actors are risk neutral and therefore the conflict payoff can be interpreted either as the probability that

\footnotetext{
${ }^{1}$ Under more restrictive assumptions, no additional insights emerge from assuming a larger set of actors; under less restrictive assumptions, assuming a larger set introduces complicating factors that obscure the main results. I will return to this issue in the paper's conclusion.

${ }^{2}$ The conflict function used in this paper is just one possible functional form for modeling conflicts or contests. A similar risk-neutral version was first used by Tullock (1980) to analyze rent seeking. Hirshleifer (1989) discussed the properties of that function and Skaperdas (1996) has provided axiomatic derivation of that and other functional forms.
} 
one of the actors wins the available consumption or as the share of the consumption that each actor retains after fighting. (Also, since $\frac{k_{i}}{k_{i}+k_{j}}$ is not defined when each actor allocates zero to fighting effort, we will assume that it equals $\frac{1}{2}$ in that case.) An actor will initiate a conflict when doing so makes him strictly better off than not initiating one. To summarize, each actor receives payoffs

$$
V_{i}\left(k_{i}, k_{j}\right)= \begin{cases}R-k_{i} & \text { if neither actor initiates a conflict } \\ \frac{k_{i}}{k_{i}+k_{j}}\left(2 R-k_{i}-k_{j}\right) & \text { if either actor initiates a conflict }\end{cases}
$$

and the timing of events in the conflict game is as follows:

1. Each actor simultaneously chooses an allocation of arming $k_{i}$.

2. Each actor simultaneously decides whether to initiate a conflict.

Given this ordering of events, what are the optimal decisions for the respective actors?

Proposition 1. There is a unique subgame-perfect equilibrium of the conflict game where each actor chooses $k_{i}=\frac{R}{2}$, neither actor initiates a conflict, and each actor receives $V_{i}\left(k_{i}, k_{j}\right)=\frac{R}{2}$.

Beginning with the stage game and using backward induction, we begin with the decision to initiate a conflict. When $k_{1}=k_{2}, \frac{k_{i}}{k_{i}+k_{j}}=\frac{1}{2}$ and it is readily seen that $R-k_{i}=\frac{k_{i}}{k_{i}+k_{j}}\left(2 R-k_{i}-k_{j}\right)$. Therefore, when $k_{1}=k_{2}$, neither actor is strictly better off initiating a conflict. When $k_{i}>k_{j}$, it can be seen that $\frac{k_{i}}{k_{i}+k_{j}}\left(2 R-k_{i}-k_{j}\right)>R-k_{i}$, since $\frac{1}{2}\left(2 R-k_{i}-k_{j}\right)>R-k_{i}$ and $\frac{k_{i}}{k_{i}+k_{j}}>\frac{1}{2}$ for $k_{i}>k_{j}$. Therefore, when $k_{i}>k_{j}$, the actor with the greater arming level prefers to attack. Given those conflict decisions, actors will choose a higher level of arming than their opponent, until decreasing returns set it. Optimal arming allocations can be found by taking the derivative of the actors' conflict payoff and solving it in terms of $k_{i}$. This gives two equations in two unknowns; solving for the optimum $k_{i}$ yields $\frac{R}{2}$. Each player's decision is symmetric.

At this arming allocation, neither actor attacks the other, since this does not improve his payoff. Thus each actor spends half his endowment in arming, does not attack, and consumes the remaining half. This allocation and conflict-decision profile is the unique subgame-perfect equilibrium of the 
stage game. Moreover, this is the equilibrium outcome in every period of the infinitely repeated game. Because actors live for only one period, strategies in any period cannot depend on what actors have done in previous periods.

Figure 1 provides an example of the decisions made in the stage game where $R=100$ and $k_{i}$ is chosen from the discrete set $\{0,1, \ldots, 100\}$.

\section{[FIgure 1 ABOUt HeRE]}

\subsection{Proprietary Protection and the State}

Moving on from the baseline model conflict game, we now introduce the role of the state into the the game of conflict. I will call this the "proprietary-state game." We introduce a new actor $L$, who we will call a patron or protector. ${ }^{3}$ The same strategies available to the actors in the conflict game are available in this version of the game that includes the state. But now actors may become clients by paying the patron a protection rent, $\tau$. In exchange, clients receive protection in the form of military support of amount $k_{L} \geqslant 0$ if the opposing actor initiates a conflict. As for the patron, supplying protection incurs a cost. Assume a cost function $C(\cdot)$ which is increasing and convex in $k_{L}$ and where $C(0)=0$. We also include a parameter $\alpha$ that indicates the state's capacity, defined as the cost efficiency with which she can deliver military support. The patron also has a discount factor $\delta \in(0,1)$. Finally, we normalize the patron's reservation utility to zero.

Because the patron takes the protection rent up front and promises to provide protection later, the patron has an incentive to renege on her promises. However, the patron is long lived and therefore has a reputation based on her history of past action. Although the actors are short lived, they have knowledge of the patron's past behavior and therefore may condition their decisions to become a client on the patron's reputation. In particular, we will assume that every generation of actors has full knowledge of the patron's past behavior and play a grim-trigger strategy wherein

\footnotetext{
${ }^{3}$ I will try to be consistent throughout this paper and use the female pronoun to refer to the patron and the male pronoun to refer to the clients. The medieval period was certainly male-dominated, but there were important exceptions where women acted as lords or patrons. Indeed, the English case we shall be examining can be regarded as one of them.
} 
the actors: (1) pay the protection rent as long as the patron credibly provides protection and (2) if in any period the patron does not supply protection as promised, refuse to pay the protection rent in every subsequent period.

The timing of events now proceeds as follows:

1. The patron chooses the level of the protection tax, $\tau$, and promises protection of amount $k_{L}$.

2. Each actor chooses whether to pay the protection tax, $\tau$.

3. Each actor simultaneously chooses an allocation of arming, $k_{i}$.

4. Each actor simultaneously decides whether to initiate a conflict.

5. The patron chooses whether to supply each actor $i$ with the promised level of protection:

(a) if $i$ is attacked by his opponent;

(b) if $i$ does not attack his opponent; and

(c) if $i$ is a client, i.e., paid $\tau$.

When both actors become clients, they then face the following payoffs:

$$
V_{i}\left(k_{i}, k_{j}\right)= \begin{cases}R-\tau-k_{i} & \text { if neither actor initiates a conflict } \\ \frac{k_{i}}{k_{i}+k_{j}+k_{L}}\left(2 R-2 \tau-k_{i}-k_{j}\right) & \text { if actor } i \text { initiates a conflict } \\ \frac{k_{i}+k_{L}}{k_{i}+k_{j}+k_{L}}\left(2 R-2 \tau-k_{i}-k_{j}\right) & \text { if actor } j \text { initiates a conflict } \\ \frac{k_{i}}{k_{i}+k_{j}}\left(2 R-2 \tau-k_{i}-k_{j}\right) & \text { if both actors initiate a conflict }\end{cases}
$$

Besides the fact that $\tau$ is now paid up front and reflected in the payoffs, the key differences between this version of the game and the previous one are that if an actor $i$ initiates a conflict, $j$ enjoys an additional level of $k_{L}$ military support from the patron; and that the patron only acts in a "defensive" fashion, by contributing support only to the side that is attacked. 
As we analyze the game with a protection-providing patron, it will be seen that the occurrence of conflict between clients becomes probabilistic for a range of protection levels. Within this range, we find that there are no pure-strategy equilibria where a strategy profile of arming that is a best response for one client is also a best response for the other. But there do exist mixed-strategy equilibria where actors have a probability distribution over arming levels.

These mixed-strategy equilibria in turn generate probabilistic occurrences of conflict. We will denote the probability that a conflict occurs as $p$. The existence of mixed-strategy equilibria in relatively large choice sets also requires the use of simulation to find such equilibria. The remainder of the paper's propositions are therefore based on simulation results. The algorithm used in the simulation to find Nash equilibrium is a best-response evolutionary dynamic derived from the work of Shamma and Arslan (2005).

What are the equilibrium outcomes of the proprietary-state game? I will begin by analyzing the clients' decisions to initiate a conflict given the patron's choices of rent and protection. Next I will analyze actors' decisions to become clients as they are affected by the patron's choices of rent and protection. Following that, we will examine the patron's incentive-compatibility constraint and maximization problem.

Proposition 2. For $k_{L}>0$, as $k_{L}$ increases, the probability of conflict, p, between clients goes to 0 .

This proposition can be seen graphically in Figure 2, where the probability of conflict is depicted using a black-to-white gradation: the probability of conflict is higher when the tone is lighter. The figure is constructed from a simulation where for every combination of $\tau \in\{0,1, \ldots, 75\}$ and $k_{L} \in\{0,1, \ldots, 30\}$, we let clients choose $k_{i} \in\{0,1, \ldots, 100\}$ when $R=100$ and assume the patron's makes good on her protection promises. This simulation generates a probability distribution over the arming set and the probability of conflict is found by summing the joint probabilities that arming allocations of both clients fall into either one of their conflict regions.

\section{[FIgure 2 ABOUt HeRE]}


At $k_{L}=0$ the probability of conflict is (virtually) zero. ${ }^{4}$ Taxation only reduces the size of each actor's resource base and, without any protection from the patron, the game is identical to the conflict game analyzed in the first subsection. Things change as we introduce increasing levels of protection. In general, it can be seen that for a given $\tau$ the probability of conflict goes to zero when $k_{i}$ becomes sufficiently high. As can also be seen, however, the relationship between $k_{L}$ and $p$ is not always monotonic (nor is the relationship between $\tau$ and $p$ ).

An example of the proprietary-state game as seen from the clients' perspective is depicted in Figure 3. In Figure 1, a single "line" denoted allocations where neither actor preferred to initiate a conflict. In Figure 3, we now see that there is a "space" of allocations for which neither actor wishes to attack the other. At each of these allocations no attacks occur; above this space, actor 1 prefers to initiate an attack, while actor 2 prefers to initiate attacks below the space. Figure 3 also depicts each actor's best-response arming levels. Note also that although some positive arming levels are best responses, none of them are in each actor's respective "attack regions." In other words, actors never prefer to initiate an attack at any best-response level of arming. As can also be seen, the allocation profile $\{0,0\}$ is a best response for both actors and the probability of conflict is zero.

\section{[FIgure 3 About Here]}

For lower levels of protection, the probability of conflict becomes positive. Figure 4 depicts such an example from the clients' points of view. As can be seen, the "no attack" region shrinks and the clients' best-response curves do not intersect. However, there are best-response levels of arming that do lie within each client's "attack" region. Thus when one client chooses a sufficiently high level of arming and the other a sufficiently low level, the first client will attack the second.

\section{[FIgure 4 About Here]}

\footnotetext{
${ }^{4}$ When risk aversion or "collateral damage" is added to the conflict game, the possibility of conflict emerges even when the amount of protection is zero. However, these versions of the game also generate multiple equilibria, complicating the analysis.
} 
How does the patron's choices of $\tau$ and $k_{L}$ affect the actors' choices to become clients? To determine whether actors prefer to become clients of the patron, we compare the payoffs actors receive when they are both clients, when one is a client and the other is not, and when they are both not clients (which are equivalent to the payoffs they receive in the baseline, conflict game). I use simulation to answer this question, and again for every combination of $\tau \in\{0,1, \ldots, 75\}$ and $k_{L} \in\{0,1, \ldots, 30\}$, clients choose $k_{i} \in\{0,1, \ldots, 100\}$ when $R=100$, and choose whether they prefer to be a client when the other actor is and when the other actor is not.

As can be seen in Figure 5, these comparisons yield four possible outcomes. The black region in the bottom right-hand corner shows the combinations of $\tau$ and $k_{L}$ for which an actor prefers to become a client whether the other actor is a client or not. On the other hand, the white region in the top left-hand corner shows combinations where an actor prefers not to become a client whether the other actor is a client or not. In between these regions are two multiple equilibria regions where an actor prefers to be a client if the other actor is a client but prefers to not be a client if the other actor is not. Among the multiple equilibria, the dark gray region depicts combinations of protection and rent where it is pareto optimal for the actors to become clients while the the light gray region shows combinations where they are worse off becoming clients. ${ }^{5}$

\section{[FIgure 5 About HeRE]}

Given the appearance of these multiple equilibria, I adopt an equilibrium-selection assumption that actors can coordinate on the pareto-optimal equilibrium. This is a fairly reasonable assumption since there is no conflict of interest between the actors about which equilibrium they prefer. It is also counterintuitive to expect that actors would choose to become clients when it makes them

\footnotetext{
${ }^{5}$ In addition, one will notice in Figure 5 a horizontal and diagonal set of white areas within the light gray area. I am currently trying to determine an explanation for these, which indicate choices of $\tau$ and $k_{L}$ at which actors do not become clients within an otherwise multiple equilibrium area. I do not think they are a product of the discrete nature of the game since when the choice set is made finer, they still appear. It is also not a product of the nonmonotonic changes in the probability of conflict that were identified earlier since the probability of conflict is zero in this region. It could be that actors choices could be sensitive to alternating impacts of changing protection and protection rent in these areas. The horizontal line is close to the level of protection rent at which actors unambiguously prefer not to become clients. And the diagonal line is close to the level of protection, conditioned on the level of protection rent, at which any additional level of protection ceases to make a difference to the clients.
} 
worse off than when they aren't. With this assumption, the border between the two multiple equilibria regions becomes the key decision line for the equilibrium choices of actors' decisions to become clients, which leads to our next proposition.

Proposition 3. Up to a threshold level of protection, $k_{L}$, the greater the amount of protection provided, the higher the rent, $\tau$, the actors are willing to pay. Conversely, the lower $k_{L}$, the lower $\tau$ the actors are willing to pay.

That decision line also assists the patron in choosing $\tau$ and $k_{L}$. This can be directly seen in Figure 5. Assuming the patron's promises of protection are credible, she will want to choose the highest level of protection rent. And since the highest level of rent is determined by the amount of protection provided, she will choose $k_{L}$ to maximize $\tau$.

The final step is to analyze the patron's incentive-compatibility constraint. If the patron reneges, her maximum deviation is to take the protection rent paid by the two clients and provide no protection. This earns her a payoff of $2 \tau$ after which the actors refuse to become clients in every future period. If she holds to her promise, she will receive the protection rent from both clients in every period, but also must incur the cost of protection when a client is attacked. According to the timing of the stage game, since the patron decides whether to provide protection after observing whether a conflict occurs, she knows with certainty if a conflict has occurred or not in the current period of the game. In future periods, she must assess the cost of protection probabilistically, according to $p$. She also need only incur the cost at most once in a period: if both clients attack each other, she is not obligated to provide protection-but neither is such an outcome possible from the nature of conflict between clients.

The patron will therefore provide protection when the protection rent she receives in every period less the cost of providing protection in the current period and the cost of the probability of providing protection in every future period leaves her at least as well off as taking the protection rent in the current period and providing no protection. ${ }^{6}$ We can write this condition formally as:

\footnotetext{
${ }^{6}$ Subgame-perfect equilibrium requires a strategy profile to be a Nash equilibrium in every subgame. Therefore, even if an attack by a client never occurs "on the equilibrium path" we must still know whether the patron would prefer to provide protection "off the equilibrium path," i.e., in the case that a client did initiate a conflict.
} 


$$
\frac{2 \tau-\delta p\left[\alpha C\left(k_{L}\right)\right]}{1-\delta}-\alpha C\left(k_{L}\right) \geqslant 2 \tau
$$

Simplifying this inequality gives us:

$$
\frac{2 \tau}{\frac{1-\delta}{\delta}+p} \geqslant \alpha C\left(k_{L}\right) .
$$

This inequality summarizes some important relationships. First, the more the patron discounts the future (smaller $\delta$ ), the less likely the inequality will hold. In addition, the smaller the protection rent (smaller $\tau$ ), the less likely the inequality will hold. Also, the smaller the capacity (or greater inefficiency) of the state (larger $\alpha$ ) or the more protection it provides (larger $k_{L}$ ) the less likely the inequality will hold. Finally, a greater probability of conflict among clients (larger $p$ ) also threatens the patron's credibility.

This condition also provides us with some intuition into how the patron chooses $\tau$ and $k_{L}$. First, as we have seen, both $p$ and the highest possible $\tau$ consistent with the actors becoming clients are determined by the patron's choice of $k_{L}$. We can therefore understand the patron's maximization problem in terms of $k_{L}$. Second, given the parameter values and the choices of $\tau$ and $k_{L}$, the actors can anticipate whether the patron will renege, given the timing of the proprietary-state game. This fact prevents the patron's reneging from ever being part of an equilibrium strategy profile. And given those two facts, the patron will therefore always choose $k_{L}$ to obtain the highest level of $\tau$ consistent with her incentive-compatibility constraint, for permissible values of the parameters. Such a choice of $k_{L}$ yields a stream of profits that is the best the patron can obtain. We can now state the next proposition.

Proposition 4. Within appropriate ranges of values for $\delta$ and $\alpha$, when $\delta$ decreases or $\alpha$ increases, the patron's incentive-compatibility constraint can be sustained by lowering the amount of protection, $k_{L}$, provided.

Using the results of simulations reported in Figures 2 and 5, Table 1 gives us the probability of conflict, $p$, that is generated and the maximum rent, $\tau$, that the patron can charge given the amount 
of protection, $k_{L}$, she promises. It is also assumed that $C\left(k_{L}\right)=k_{L}^{2}$. Given those relationships, we can draw comparative-statics results for changing values of the parameters, $\delta$, the discount factor, and $\alpha$, the level of state capacity. Columns (4) and (5) of Table 1, for example, provide values for the left- and right-hand sides, respectively, of inequality (2) with parameter values of 0.9 and 1 for $\delta$ and $\alpha$ respectively. The inequality holds at the patron's most preferred protection level, since it yields the highest possible tax, which is 49; the patron will therefore promise a level of protection of 14. Consider now a change in the patron's discount factor, a decrease from 0.9 to 0.6. Comparing column (6) (which represents the left-hand side of inequality (2)) of Table 1 with column (5) (the right-hand side of inequality (2)), the maximum $k_{L}$ which is consistent with the patron's incentive-compatibility constraint is 7, and hence the maximizing choice of $\tau$ is 32 . Next consider an increase in the state's inefficiency, an $\alpha$ change from 1 to 5 , with $\delta$ at the original value of 0.9. Comparing columns (4) and (7), the maximizing provision of protection becomes 3 and the maximum protection rent 22. Finally, considering a change in both $\delta$ and $\alpha$ to their new levels, we can observe by comparing columns (6) and (7) that the maximizing choice of $k_{L}$ is 2 , which earns a rent of 18 .

[TABLE 1 ABOUt HeRE]

\section{The Reign of King Stephen, 1135-1154}

We now turn towards the analysis of an empirical application of the proprietary-state game. Along with weak, failed, and collapsed states that we observe with distressing frequency in today's world, medieval Europe provides another crucial empirical source for the analysis of such quasi-states. Indeed, King Stephen's political troubles caused by the conflict over the right of succession to the English crown display several striking similarities to modern cases of failed states: insurgency and civil war, fragmentation and weakening territoriality of the state's jurisdiction, increasing levels of violence and disorder, and yet the persistence of some measure of central government. The next subsection will provide a historical background to Stephen's reign. This subsection may be 
skipped by those wishing to go directly to the historical analysis in the next subsection.

\subsection{Historical Background}

On the night of December 1, 1135, King Henry I of England (and Duke of Normandy) died at Lyons-la-Forêt in Normandy. As King (1994a) succinctly puts it: "Fifteen years after the loss of his son and heir he left behind not a secure succession but a power vacuum ..." (p. 8). Although Henry had made members of the Anglo-Norman nobility swear oaths to recognize his daughter, Matilda, as his lawful successor, she was married to Geoffrey, the count of Anjou (Matilda had been married to the German Emperor Henry V in 1114 and was widowed in 1125). Anjou was traditionally a rival of Normandy. Three weeks later, the Norman barons had almost decided to elect a nephew of King Henry, Theobald Count of Blois, to become king "when a messenger arrived from England to say that Theobald's brother Stephen had already been accepted as king" (Davis, 1990, 16). The mother of Stephen and Theobald was Adela, sister of King Henry and the only daughter of William the Conqueror, the first Norman king of England. Stephen first appears in 1113 as a member of King Henry's entourage. As a younger son of nobility, Stephen had gone to King Henry's court to make his way, which was not a bad decision given the contemporary wealth and prestige of King Henry and his kingdom.

Stephen had moved with stunning speed to secure the crown. After first securing the support of London (ibid., p. 10), Stephen next traveled to Winchester, where he met his other brother, Henry of Blois, who was also bishop of Winchester. Bishop Henry helped Stephen win the further support of Roger Bishop of Salisbury, who controlled the treasury and government administration. Also through Bishop Henry, Stephen agreed to a charter of liberties for the Church, which played no small part in convincing William de Corbeil, archbishop of Canterbury, to anoint Stephen king, which occurred on December 22, 1135. The result of these maneuvers was that by March 22, 1136, the date of Stephen's Easter Court, his hold on the kingdom of England seemed secure.

However, in the next few years a series of events would cause Stephen's political support to unravel and his political survival to be called into serious question. As mentioned, there was signifi- 
cant discord in Normandy as a result of the succession uncertainty; to make matters worse Geoffrey Count of Anjou had invaded the duchy in 1136. Stephen had therefore gone to Normandy to put things in order, but by 1137 had still not been able to conclude a decisive control. On September 30, 1139, Empress Matilda arrived in England and civil war "began in earnest" (Crouch, 2000, 103). Among her entourage was Robert Earl of Gloucester, her half-brother and an illegitimate son of King Henry I, who had formally renounced his homage to Stephen in 1138 and turned over areas of Normandy in his control to Matilda's husband, Geoffrey of Anjou. A powerful magnate in his own right, Earl Robert's role and support in his sister's cause proved to be important.

In early 1140, events show Stephen acting with vigor, racing about England, struggling to address one crisis or another. Nevertheless, it appears that he was able to effectively contain the empress's party in the southern border of Wales and lower Severn valley. Real disaster seems to have struck Stephen in February of 1141 when he was captured at the Battle of Lincoln. With Stephen imprisoned in Earl Robert's castle at Bristol, it must have appeared to the empress—and many others - that it was only a matter of time before the kingdom was hers (Davis, 1990, 44-51). However, despite the king's captivity and the apparent faithlessness of his magnates at Lincoln, Stephen still maintained many dogged supporters, including his queen, Matilda; William of Ypres, his Flemish mercenary captain; and the citizens of London. While the empress was besieging Bishop Henry's castle at Winchester, the queen responded with a force led by William of Ypres. As fate would have it, Earl Robert was captured in the rout. "With the capture of the earl, the Rout of Winchester became the perfect counterpart to the battle of Lincoln, undoing almost everything the earlier battle had done" (Davis, 1990, 60). An exchange of Stephen for Robert was made between November 1 and 3, allowing the war to continue "as if the thirty-two weeks between the two battles had never existed" (ibid.).

Despite continued attempts by each side to advance its position in 1142, affairs appear to have settled into an even deeper stalemate by 1143 . The most decisive event in 1144 occurred not in England, but in Normandy, as Geoffrey of Anjou completed his conquest of the duchy and was invested as duke by the King of France in April. Again, the time seemed ripe for peace talks, 
but "Stephen was so convinced of his strength in England, and the empress of her husband's in Normandy, that neither was prepared to compromise" (ibid., p. 91). The next most significant event was the death of Earl Robert of Gloucester. While in Bristol attempting to reassemble an army and renew the campaign he became ill and died on October 31, 1147. Crouch (2000) argues that the empress's campaigns had exhausted her party by 1144, but that it "would not be too far short of the truth to suggest that the death of Earl Robert of Gloucester marked the effective end of the civil war" (p. 221). "The empress did not stay in England longer than four months after the death of Robert of Gloucester" (ibid., p. 239). She never returned to England.

With the empress now having capitulated, observers looked to her son Henry for an attempt to resume the Angevin claim to the English crown. In 1149, Geoffrey of Anjou handed over the governance of the duchy of Normandy to Henry, who was formally invested by King Louis VII of France in 1151. Eustace, Stephen's heir, died suddenly in August 1153, an event that actually removed a major obstacle to a final agreement between Stephen and Henry. Under a settlement negotiated by Theobald, archbishop of Canterbury, and Bishop Henry, "Stephen received the homage of Duke Henry" and "Duke Henry ... was acknowledged as Stephen's successor and heir to the kingdom by hereditary right" (Davis, 1990, 119). If the civil war had effectively ended in 1147, its more threatening and imminent legacies were now resolved by 1153. King Stephen died the next year, and Duke Henry came to the throne without incident.

\subsection{Analysis}

To recap the model, some of the propositions used in the empirical analysis of King Stephen's reign are summarized here:

1. Patrons whose capacity is weakened (a higher $\alpha$ ) or chances of survival fall (a lower $\delta$ ) must reduce the level of protection they provide (a lower $k_{L}$ ) in order for protection promises to be credible.

2. As the patron lowers the amount of protection promised below a certain threshold, the prob- 
ability of conflict (larger $p$ ) between actors increases.

3. Lowering the level of promised protection also requires lowering the protection rent (lower $\tau)$ to keep clients participating in the protection regime.

4. Despite reduced protection levels, lower rents, and intermittent conflict, a patron's promises of protection may still be credible and the proprietary state may continue to exist.

Most of the interpretation of variables in the empirical case is fairly straightforward. The arming variable $k$ stands for those resources commonly employed by medieval kings and aristocracy: castles and soldiers. The discount factor $\delta$ will be construed objectively, as the patron's survival rate. The variable most in need of translation in the empirical case is $\tau$. It is of course easiest to see $\tau$ as a kind of tax. But I also interpret it more broadly as the patron's or ruler's authority. Medieval rulers made several kinds of claims on their subjects (or clients), such as the right to dispense justice in addition to claims of fiscal support. As will be demonstrated below, even these "rights" yielded streams of revenue. This financial dimension of governmental authority no doubt explains the cause of their desirability—by kings and the medieval military alike.

The following sections provide evidence in support of the model's claims. Obviously, the Matilda's challenge to Stephen's rule cast into doubt the future security of his rule. And though it is uncontentious that Stephen's ability to provide protection was hampered by the civil war, I will provide evidence that this was perceived to be the case at the time. Next, I will provide evidence that Stephen's reduced protection as well as political authority, particularly revenue claims, during his reign. In the case of his creation of earldoms, Stephen appears to have anticipated his dilemma and promoted conflict and the fragmentation of authority by shifting responsibility for protection to local lords and magnates. Following this, I will discuss the impact of weakened protection on the nobility. There is evidence of both increased arming and self-protection, seen in the building or refortification of castles, as well as increasing conflict, recognized in contemporary historians' horrified reactions to the violence of the period. Finally, despite the reduction of protection and weakening of central authority, some measure of central governance remained, as attested to by 
the continuing activity of Stephen's chancery and treasury.

Before discussing the evidence which bears directly on the model's predictions, I want to address two contextual points, the first about the continuity of English governance at the beginning of Stephen's reign and the second about the role of protection in medieval society generally.

\subsubsection{Continuity of English Governance at the Start of Stephen's Reign}

Lest it be thought that Stephen's action during the civil war reflected merely a different style of governance from that of his predecessors, as some historians have suggested (Warren, 1987), I will provide some evidence that, in the beginning, Stephen's approach toward governance was continuity with the previous reign of Henry I. Henry's reign has the well-earned reputation of strong and stable governance, widespread peace, and, in contemporary circumstances, unprecedented levels of centralization. There is evidence of both demilitarization among the military classes (Scammell, 1993; Stenton, 1961) and remarkably high levels of revenue generated by his stable government (Bartlett, 2000, 175-77).

Soon after Henry's death, Stephen drew up the Constitutio Domus Regis, "a comprehensive guide to household [i.e., medieval administrative] arrangements" that in its details reveals "clearly an underlying concern for continuity" (White, 1994, 118). By retaining Bishop Roger of Salisbury at the head of his administration, Stephen was employing the skill, knowledge, and expertise of one of Henry's most innovative administrative servants. With respect to other members of the administration, he otherwise left "the old guard in place" (ibid., 119). In addition, "royal justice ... seems to have been active in the early years of the reign and to have encompassed serious crimes, transgressions of royal rights, settlements between tenants-in-chief, and cases to which the king had been alerted, much as it had done under Henry I" (ibid.). Stephen's financial administration also appears to continue the methods of his predecessor. "Stephen's early writs and charters assume a system for the collection, assignment, and accounting of revenues in full working order" (ibid., p. 121). 


\subsubsection{The Role of Protection in Medieval States}

Because the model bases is based on a "contractual" view of the state (for a discusison of the term, see Moselle and Polak, 2001), where the ruler provides protection in exchange for taxes, it is appropriate to demonstrate that this the way medieval rulers and other actors also thought about the state. Indeed, it appears that an important and perhaps the central obligation of medieval kingship was the provision of protection and the maintenance of order. In medieval England, contemporary legal and political treatises spoke of the importance of "arms and laws" in maintaining peace and order (Glanville, 1965; Bracton, 1968; Fortescue, 1997). In their coronations, medieval kings often swore to provide justice and keep the peace, notably sometimes in contrast to the failures of their predecessors. Further, these treatises and proclamations did not merely reflect desired sentiment or yearning for the past. Medieval rulers spent much of whatever wealth they possessed on military fortifications and personnel not just for external conquest and defense, but also, if not more so, as a means of internal order. R. Allen Brown (1955), writing about royal castles in a time when the English kings were particularly adept at enforcing the peace, says:

Committed to the keeping of trusted officials, often the centres of local government, at all times an impressive display of regal power, and ready in time of emergency to be rapidly stocked and garrisoned to encourage and enforce the loyalty of surrounding districts, the royal castles were, in the phrase of a contemporary writer, 'the bones of the kingdom'. (P. 361)

Even in providing for the just resolution of disputes, the concern for public order was not far from the minds of medieval rulers. According to the legal historian John Hudson (1996), "The king had to ensure the availability of peaceful solutions ..." for failure to do so "would have been a recipe for a multitude of private wars" (p. 145).

What held generally for English kings and other medieval rulers was true for Stephen as well. Crouch $(2000,136-37)$ comments on several well-known "public order" cases in which King Stephen was involved. Crouch also notes the significance of the king's capacity for keeping the 
peace in such cases once the civil war had fully come to a head:

[B]y 1140, any such attempt at a public showdown with a rival or with the king could not ignore the fact that there was in the kingdom a conflict going on which was of quite a different order-an open war of succession. All local difficulties then automatically became more serious, because they exerted pressure on a king with few resources and little time to spare. ... To maintain credibility, the king had no choice but to take as an act against him any disorder outside the war zone in the Marches. (P. 137; emphasis added)

In this passage, Crouch not only identifies the centrality of protection and the maintenance of public order in medieval governance but also the importance of Stephen's credibility and the increased difficulty in meeting this obligation in the midst of a civil war.

\subsubsection{Political Survival and State Capacity}

The literature on weak and failed states identifies a host of factors that can affect the state's integrity. As mentioned above, among these are ethnic conflict leading to insurgency, the decline of international aid, and the proliferation of private arms dealers and mercenary firms. Without discounting other causes, I highlight two particular factors that can affect a patron's credibility. The first is insurgency, which can be captured in the patron's discount rate when interpreted as her chances of survival into the next period. The second such structural factor is a worsening of the state's capacity, that is, an increase in the cost of providing a unit of protection.

A military challenge to a ruler's claim to authority, such as that launched by Matilda against her cousin Stephen, obviously throws doubt onto the ruler's future. Such an act must have reduced Stephen's credibility. The allocation of resources to fighting the civil war must have also increased the cost of meeting Stephen's protection responsibilities. We have already mentioned one historian's observation of Stephen's stretched resources. This view is also apparent in the chronicle sources. The Gesta Stephani (Potter and Davis, 1976), written by a royalist chronicler, gives an evocative account of the burdens that Stephen faced: 
Having finally been victorious over Castle Cary ... the king hastened, always armed, always accompanied by a host, to deal with various anxieties and tasks of many kinds which continually dragged him hither and thither all over England. It was like what we read of the fabled hydra of Hercules; when one head was cut off two or more grew in its place. (P. 69)

Such conditions must have taxed Stephen's resources and peace-keeping duties.

According to the model, a patron will reduce the the amount of protection promised to clients. Though it is impossible to measure the amount of protection Stephen provided, it is evident from the proceeding statements and as can be gleaned from the evidence below that Stephen reduced the amount of protection he provided.

\subsubsection{Reduction of Protection and Fragmentation of the State}

An important feature of failed states is fragmentation and the loss of territorial integrity: an increase in autonomy at the local level and the shortening reach of the central government's influence and control. The model captures this dimension of failed states as a decrease in the amount of protection the ruler provides as well as in the level of tax she levies on her clients. In the model, once the amount of protection has been reduced, the patron must also reduce the protection rent—or more broadly, the level of authority - in order to keep clients participating in the protection regime. In the case of King Stephen, perhaps the clearest example of this process is his numerous creation of earldoms (see Table 2). With the creation of these earldoms we see both the reduction of protection responsibility and the reduction of tax and royal authority as new earls became more responsible for providing protection for themselves and for the territorial subunits they governed and as they assumed revenue rights formerly held by the king.

\section{[TABle 2 ABout HeRE]}

To provide some context, Stephen's approach to earldoms was novel, both in number and nature, compared to the practice of previous and subsequent kings. Under the previous reigns of 
William the Conqueror, William Rufus, and Henry I, there were never more than seven earldoms, some lapsing or destroyed under one reign and new ones created or revived under other reigns. "[By] the time of Stephen's accession in 1135 there were still only seven earldoms: Huntingdon/Northampton, Buckingham, Chester, Gloucester, Leicester, Surrey, and Warwick” (Bartlett, 2000, 208). In contrast to these previous reigns, earldoms proliferated under Stephen. "Stephen created earldoms freely, and made 19 appointments" (Warren, 1987, 92). The timing of these creations is critical: as can be seen in Table 2 and as Hollister (1994) nicely summarizes, Stephen "instigated the policy [regarding earldoms] in the latter part of 1138 and it reached full throttle around 1140" (p. 60). Also from Table 2, it will be noticed that five counties did not have earls. In these cases, however, the exception proves the rule. Davis (1990) explains:

In Kent William of Ypres had everything but the title of earl, and was probably denied the title so as not to suggest that he was reviving his claim to the county of Flanders. It is likely that in Hampshire, the earl's duties were performed by the bishop [Henry] of Winchester. Berkshire would have been dependent on Windsor Castle and Middlesex on the Tower of London. (P. 125)

A probable reason why no earl was created in Shropshire was that it was in the hands of Henry I's widow, Queen Adeliza, who received it by her marriage to the king and who did not die until 1151 (ibid., p. 140).

More important than the numbers, however, is the nature of Stephen's new earldoms. Prior to Stephen's reign, the status of an earl was largely honorific. ${ }^{7}$ Latimer (1986) notes that these "earls were powerful men, but not through the rights conferred on them by comital office" (p. 137). The only exception in 1135 was the earl of Chester, who held "almost complete lordship" over the shire of his earldom (ibid.). Yet, while under Henry I, England's counties (or shires) were "political subdivisions administered by [royal] sheriffs and royal justices," under Stephen they became "semi-autonomous districts governed by earls" (Hollister, 1994, 55). Hollister elaborates: "[B]y

\footnotetext{
${ }^{7}$ In fact it was the only formal honorific title held by members of the English aristocracy at this time. Bartlett (2000) also explains that the word "earl" was of "Anglo-Scandinavian origin and scribes writing in Latin rendered it as comes, equivalent to the French 'count"' (p. 208).
} 
and large earls replaced sheriffs as castellans of formerly royal castles; they became dispensers of formerly royal justice; and in many instances they received great tracts of formerly royal demesne lands. In four shires, earls served as their own sheriffs. Some earls even minted their own coins" (ibid., p. 60).

With more specific reference to the model's claims, the creation of these earldoms reveal a shift in protection activity from Stephen to these new magnates at the local level. For Davis (1990), the grant of an earldom came with a responsibility to defend the county to which the grant was attached. According to Crouch $(2000,87)$, "there was a novel military and administrative dimension" to these new earldoms. Going further than any other historian, Warren $(1987,94)$ even contends that "the shift of power from central to local control was an alternative conception of government" rather than a political expediency precipitated by the insurgency. Dalton's (1990; 1994) study of Yorkshire brings out this shift of protection in particular detail. Stephen's initial approach to Yorkshire, a county in the far north of England, was to maintain Henry I's administrative system (Dalton, 1994, 148). However, by 1138 he was “in danger of losing control in the north" (ibid., p. 150). A chief reason for this potential loss of control was his "failure to provide security" to prominent Yorkshire magnates (ibid., pp. 148-51), partly because he was preoccupied with the war in the south (ibid, p. 152). In the same year, Stephen appointed William of Aumale as earl of York to address the problem of security (ibid.). As with other earls, William assumed control over the key military fortifications that a protector of the county would be expected to have (ibid., pp. 152-55).

To keep clients participating in the protection regime, patrons must reduce tax or other authority claims as well as the amount of protection they provide. Under Stephen, this is displayed in the devolution of regalian rights and in particular fiscal and monetary rights. Mention was previously made of the shift in control of sheriffs from king to earls. In the Anglo-Norman system of finance, the sheriff for each county was responsible for collecting the king's revenues and delivering accounts annually at the Exchequer (Bartlett, 2000, 149-51). Revenues came in the form of income from royal lands, feudal aids and incidents, taxes, and the profits of justice. Since the sheriff was 
expected to deliver a fixed payment and keep the residual, the potential for profit was considerable. During Stephen's reign, in numerous cases it can be shown either that the earls acted as their own sheriffs in the counties or that the sheriffs simultaneously served as earls' officials, such as stewards or constables, indicating the extent to which the sheriffs became accountable to the shire's earl rather than directly to the king (Davis, 1990; Green, 1992). Green $(1992,104)$ also suggests that it was possible that royal taxes, such as the Danegeld, were shared with local magnates. Finally, Green makes the link between increased military obligation and the reduction of revenue claims direct, even if limitations in the evidence makes the king's explicit acknowledgement of this connection a bit speculative: "If it is borne in mind that earls may have been expected to take over the defence of their counties, and that they could bring strong pressure to bear on their sheriffs, it is possible that they siphoned off royal revenue in recompense for their expenditure on the king's behalf" (ibid., p. 102).

This evidence of fragmentation and devolution of political control is consistent with key claims of the model. During Stephen's reign there was a decrease in protection from the center as well as a reduction in royal revenue and tax claims. However, to address competing explanations for the creation of earldoms, three other points ought to be mentioned. First, the earls' new military responsibilities were not simply to carry out the prosecution of the civil war. Though Stephen created earls of the new type in "vulnerable" areas such as York, Pembroke, and Worcester he also granted them in other areas too: "neither Lincoln, Nottingham nor Derby were front-line areas" (Crouch, 2000, 88). Such a policy is consistent with an attempt to respond to problems of credibility by devolving peace-keeping authority even in regions under his nominal control. Second, Stephen's policy toward earldoms was not peculiar to himself. Matilda also created new earldoms, particularly during her short period of ascendency, as can also be seen in Table 1. Since she undoubtedly had credibility problems of her own, this is consistent with the claims of the model, rather than a theory that Stephen was following a preconceived, personal policy. Third, although patronage was undoubtedly a rationale in the making of these earldoms, most historians agree that such motives are insufficient explanations. Commenting on their security and administrative roles, 
Crouch (2000) writes, "[P]atronage and reward were only part of these promotions ..." (p. 87).

I remark in passing on another feature of failed states: the emergence of what might be called "protection intermediaries." In response to a decrease in the capacity of a government to provide political goods, Rotberg (2003) writes, "Citizens then naturally turn more and more to the kinds of sectional and community loyalties that are their main recourse in time of insecurity .... They transfer their allegiances to clan and group leaders, some of whom become warlords." One of the more remarkable aspects of Stephen's creation of earldoms is his attempt to manage this process and address the gap left in providing protection by formally handing such functions onto trusted intermediaries. The model does not explicitly capture such protection hierarchies, but this would be an interesting extension. For now, it suffices to demonstrate the shift in protection and revenue claims, while the conscious creation of earls reveals that Stephen was aware of the dilemma he faced. It is also worth noting that, just as warlords in contemporary failed states frequently pursue their own private ambitions, often in contravention to central authority, medieval lords in Stephen's England, even those he appointed as earls, acted no differently. This will be shown in the next subsection.

\subsubsection{Self-Protection, Arming, and Conflict}

Another indication of state failure is an increasing level of disorder and violence. In the model, a reduction in the patron's protection forces clients to shift to a greater amount of self-protection, which in turn leads to an increase in the probability of conflict. Indeed, a florescence of "baronial autonomy" (Stenton, 1961, 218) is a persistent theme in the historical literature: "baron" being the contemporary term for a member of the military elite and "autonomy" referring to the degree that individual members of this elite became responsible for their own protection and pursuits. There is evidence both that barons increased their expenditure on $\operatorname{arming}^{8}$ and that the chances of conflict increased.

\footnotetext{
${ }^{8}$ I have not demonstrated that the expected costs of arming (i.e., higher $k_{i}$ and $k_{j}$ ) will result from a decrease in protection, but it should be easy to do so. The expected cost at least increases because $p$ increases, but the sizes of $k_{i}$ and $k_{j}$ in each player's strategy support probably increase as well.
} 
As to military expenditure, the chronicle sources make plentiful references to the use and construction of castles and other military fortifications. The writer of the Anglo-Saxon Chronicle says: "Every man built castles and held them against the king [Stephen]. They filled the whole land with these castles" (King, 1984, 135). William of Malmesbury tells a similar story: “There were many castles throughout England, each defending its territory or, to tell the truth, plundering it" (Bartlett, 2000, 284). Again, the year 1138—-that important year of Earl Robert's "defiance"—is crucial for the timing. "This was a year, seen from the cloister at Winchester, one of the most stable environments in Britain, when 'there was no man of any rank or standing in England who did not build anew and munition his fortifications"” (King, 1994a, 14).

It is important to point out that the arming among Stephen's barons was not driven by the civil war between Matilda and Stephen, neatly dividing barons into the two contending sides. Though undoubtedly military resources were put to use in each contender's cause, particularly by their more energetic adherents, military build up was also or even largely an individual and autonomous reaction to Stephen's weakened capacity to maintain public order. Crouch (2000) gives a compelling account of the individualized dimension of these confrontations among the nobility. Thus the strains of the civil war and the uncertainty of Stephen's survival created a "new territorial dilemma" at the local level: barons went to war with "their neighbors (of whatever party)" as much as in support of the king or empress (ibid., pp. 150-51). Crouch details several cases of regional nobles pursuing their territorial ambitions (ibid., p. 157-60, 162-65). Even magnates that Stephen had appointed as earls, such as William of Aumale, used the weakening of centrally-provided protection to pursue their own private objectives, sometimes subverting the king's own interests (Dalton, 1994, 152-95).

It also likely that there was an increase in conflict among the barons during Stephen's reign. Older historians, such as Davis (1903) argued that the amount of conflict was widespread and devastating. There are three sources for the claim of increased conflict. First, the chronicler accounts of violence are abundant (Hollister, 1994, 50). In addition, private charters from during the reign make allowances for tenants or recompense religious houses for losses or damages sustained 
during the war (ibid., p. 51). A third source of evidence comes from the financial records at the beginning of Henry II's reign. The remarkably high incidence of "waste" in these records has been interpreted as lands that were devastated and on that account unable to pay taxes (Davis, 1903).

Despite this evidence, the extent of conflict during Stephen's reign is one of the most debated topics in the historical literature. Even if virtually all historians agree on a devolution of political power, they differ over just how much conflict resulted from "public disorder." For his part, Crouch (2000) argues that public-disorder driven conflict was limited in time and place to those "regions where the influence of King Stephen and his Angevin enemies met” (p. 161). As it was suggested earlier, there is reason to see chroniclers' histories as "church propaganda" and so these contemporary narrative sources may be discounted. Also, much debate has also centered on the meaning of the word "waste" in Henry II's early financial records. Some contend that it meant that taxes could not be collected, for example, because it simply couldn't be determined who owed (Crouch, 2000, 6-7) and not necessarily because they were desolated by war. Though I provide no evidence to settle the debate, it is interesting that the model may be able to theoretically accommodate both views. Since occurrence of conflict is probabilistic rather than dichotomous, the emergence of intermediate levels of conflict is a possibility.

\subsubsection{The Survival of Stephen and the English State}

Were the political changes of Stephen's reign a state "failure" or a complete "collapse" of governance, to use the terminology introduced in the introduction? In the model, the protection rent, interpreted as a measure of state authority, may vary. Further, the payment of these rents is not inconsistent with a positive level of conflict and disorder. Therefore the model is able to capture degrees of "stateness" and thereby accommodate the variation in types of states identified in the empirical literature. In Stephen's case, despite the level and significance of this territorial devolution, a degree of central government remained in operation throughout the civil-war period, though on a reduced scale as should be expected.

For instance, White (1994) finds the central government operating up to the battle of Lincoln 
in 1141 . We have already argued this to be the case up to 1138 , when Stephen began creating earldoms. But even between 1138-41, we are given "the impression that the business of government continued much as before, outside the Angevin southwest" (ibid., p. 123). Thus Stephen continued to employ several central government officials, including the chamberlain and chancellor, and there was no drop in the output of royal charters. Further, royal charters indicate that burghal revenues were being handled as usual and that confirmations of property, a routine royal function, were being made. Yoshitake (1988a) also supports the case for the operation of central government up to 1141 . He finds "no evidence of a serious shortage of chancery staff" and even discovers some innovation in the legal writ system, "namely, the development from purely executive writs towards judicial writs" (p. 105). With regard to finances, if Stephen "was short of money by 1139, this seems to have had far more to do with heavy expenditure than with any problems in raising income" (White, 1994, 192).

What about after the battle of Lincoln? Yoshitake (1988a) makes the case that the king's capture in 1141 was the real disaster for central government, a view which is endorsed by White (1994). Nevertheless, during the period of Stephen's captivity, central government appears to survive under the empress. Indeed, the writs and charters issued by Empress Matilda are very illuminating. In a charter issued for Geoffrey de Mandeville, it was specified that the revenues owed from the counties of Essex and Hertford were $£ 300$ and $£ 60$, respectively (Yoshitake, 1988b, 957). Compare these figures to what they both owed under Henry II: $£ 645$ (ibid.). This agreement is significant in two ways since, on the one hand, it shows that Geoffrey was able to keep a significant share of the county's revenues, but on the other hand, that revenue was still expected to be paid to the center (White, 1994, 129).

Following Stephen's release, White (1994) argues that "royal government obviously continued in the period 1142-53, albeit on a much reduced scale" (p. 130). Stephen continued to employ a scaled-down, household administrative staff. The condition of royal finances is again revealing. The early Exchequer records of Henry II's reign record that some county revenues were paid in "tale" (i.e., by the face value of the coins) while others were paid in "blanch" (i.e., in assayed 
coin). ${ }^{9}$ What is interesting is that these groups of counties have a regular geographic distribution: the counties that paid in tale are found in eastern England and those in blanch in western England. Since these regions correspond to the areas of control under the empress and Stephen, respectively, this evidence suggests the continuation of practices under the previous reign and more importantly the continuation of taxation and the survival of the Exchequer during the civil war (see also Cronne, 1970, 221-36). Yoshitake (1988b) concludes that "it is quite plausible that even in the civil war the Exchequer worked to some degree in eastern England under Stephen and in western England under the Empress Matilda, even if with some disorder" (p. 958). The payment in tale is also another indication of financial devolution, since the practice would benefit the sheriffs (and earls) making payments to the Exchequer. It was not until 1166 that the Exchequer records resume the order and detail of Henry I's sole surviving financial record of 1130 (ibid., p. 952). Regarding taxes such as the Danegeld, Cronne (1970, 229-30) suggests that if quittances were being granted, then it is likely that the tax was still being levied as well (quittances, but not levies, would have been recorded in royal charters). Also with respect to finances, Green (1992) adds: “[W]hen Stephen was released from captivity he carried on the fighting and did not noticeably run out of funds. He was even able to pay off Henry of Anjou's mercenaries in 1147, and it was not financial exhaustion that brought him to terms with his rival in $1153 \ldots "$ (p. 91).

\section{Conclusion}

This paper has argued for a novel explanation for state failure, the process whereby states experience increasing territorial fragmentation, conflict, and violence, and yet some semblance or degree of central state authority persists. The argument hinges on the ruler's need to maintain credibility. One way to do this is by lowering the amount of protection the ruler provides. This reduces the costs of maintaining the state and therefore makes future promises of protection credible. However, since protection is reduced, clients act more autonomously since they have to provide more

\footnotetext{
${ }^{9}$ These different methods of payment were developed throughout the Anglo-Norman period, the latter method intended to protect royal revenues from clipped or debased coins (Yoshitake, 1988b, 950-51).
} 
for their own protection, and this contributes to a fragmentation of the state and its possession of a "monopoly of violence." With reduced protection levels also comes increasing probabilities of conflict and violence.

Further, I have argued that the events of King Stephen's reign can be explained within this model. A contest to claim the crown weakened Stephen's credibility, who reacted by devolving protection responsibility and revenue claims down to new earls, who as local power holders stepped in to fill the void. And although the civil war between Matilda and Stephen was a source of conflict, more important for the model and the nature of failed states was the degree to which weakening protection and security contributed to an endemic of militarization and probable conflict between local barons and lords of whatever party.

The explanation offered in this paper-the introduction and tolerance of some degree of political disorder as a price to pay to maintain credibility and some state integrity-differs from previous explanations of state failure. Rather than a "penchant for predation" that sends states over the brink, as Bates (2008) emphasizes, this paper claims that the state may weaken even as the ruler makes good on its promises of protection. This is not to discount predation, which is certainly a plausible source of insurgency and loss of legitimacy. But rulers also need allies, even to sustain their illegitimate rule, and this inevitably requires some ability to maintain credibility. This explanation also differs from Reno $(1997,1998)$, who argues that rulers take the step toward warlord politics by destroying state institutions as a means of denying rivals access to resources. But in the account presented here, central government is downgraded not to destroy sources of patronage, but as a result of a shift in protection provision: since more of the resources are now being controlled at the local level, with lords providing more for their own protection, less revenue is flowing to the central administration. Yet while the proposed mechanism contrasts with these previous approaches, this does not mean that the mechanism proposed here is exclusive, even if general. The goal of this paper, rather, has been to think about other possible explanations for state failure. How this mechanism combines or displaces other mechanisms is a subject for future research. 


\section{References}

Barthélemy, Dominique. 1990. L’ordre seigneurial : XIe-XIIe siècle. Paris: Seuil.

Bartlett, Robert. 2000. England Under the Norman and Angevin Kings, 1075-1225. Oxford: Clarendon Press.

Bates, Robert, Avner Greif and Smita Singh. 2002. “Organizing Violence.” Journal of Conflict Resolution 46(5):599-628.

Bates, Robert H. 2008. When Things Fell Apart: State Failure in Late-Century Africa. Cambridge: Cambridge University Press.

Bates, Robert H., Avner Greif, Margaret Levi, Jean-Laurent Rosenthal and Barry R. Weingast. 1998. Analytic Narratives. Princeton, NJ: Princeton University Press.

Bracton, Henry de. 1968. On the Laws and Customs of England. Cambridge, MA: The Selden Society and the Belknap Press of Harvard University.

Brown, R. Allen. 1955. "Royal Castle-Building in England, 1154-1216." English Historical Review 70(276):353-98.

Collier, Paul and Anke Hoeffler. 2004. "Greed and Grievance in Civil War." Oxford Economic Papers 56(4):563-96.

Cooper, Neil. 2002. "State Collapse as Business: The Role of Conflict Trade and the Emerging Control Agenda." Development and Change 33(5):935-55.

Cronne, H.A. 1970. The Reign of Stephen, 1135-54: Anarchy in England. London: Weidenfeld and Nicolson.

Crouch, David. 2000. The Reign of King Stephen, 1135-1154. Harlow, UK: Pearson Education.

Dalton, Paul. 1990. "William Earl of York and Royal Authority in Yorkshire in the Reign of Stephen.” Haskins Society Journal 2:155-65.

Dalton, Paul. 1994. Conquest, Anarchy and Lordship: Yorkshire, 1066-1154. Cambridge, UK: Cambridge University Press.

Davis, H.W.C. 1903. “The Anarchy of Stephen's Reign.” English Historical Review 18(72):630_ 41.

Davis, R.H.C. 1990. King Stephen, 1135-1154. 3rd ed. London: Longman.

Dixit, Avinash. 2003. “On Modes of Economic Governance.” Econometrica 71(2):449-81.

Dixit, Avinash K. 2004. Lawlessness and Economics: Alternative Modes of Governance. Princeton, NJ: Princeton University Press.

Ermakoff, Ivan. 2008. Ruling Oneself Out: A Theory of Collective Abdications. Durham, NC: Duke University Press. 
Fearon, James D. and David D. Laitin. 2003. "Ethnicity, Insurgency, and Civil War." American Political Science Review 97(1):75-90.

Fortescue, Sir John. 1997. On the Laws and Governance of England. New York: Cambridge University Press.

George, Alexander L. and Andrew Bennett. 2005. Case Studies and Theory Development in the Social Sciences. Cambridge, MA: BCSIA Studies in International Security and MIT Press.

Glanville, Ranulf de. 1965. Tractatus de legibus et consuetudinibus regni Anglie qui Glanvilla vocatur. London: Nelson.

Green, Judith. 1992. “Financing Stephen’s War.” Anglo-Norman Studies 14:91-114.

Greif, Avner. 2006. Institutions and the Path to the Modern Economy: Lessons from Medieval Trade. Cambrdige: Cambridge University Press.

Grossman, Herschel I. and Minseong Kim. 1995. "Swords or Plowshares? A Theory of the Security of Claims to Property." The Journal of Political Economy 103(6):1275-1288.

Hirshleifer, Jack. 1989. “Conflict and Rent-Seeking Success Functions.” Public Choice 63(2):10112.

Hirshleifer, Jack. 2000. “The Macrotechnology of Conflict.” The Journal of Conflict Resolution .

Hollister, C. Warren. 1994. The Aristocracy. In The Anarchy of King Stephen's Reign, ed. Edmund King. Oxford: Clarendon Press pp. 37-66.

Hollister, C. Warren and John W. Baldwin. 1978. "The Rise of Administrative Kingship: Henry I and Philip Augustus.” American Historical Review 83(4):867-905.

Hudson, John. 1996. The Formation of the English Common Law: Law and Society in England from the Norman Conquest to Magna Carta. London: Longman.

Jackson, Robert H. and Carl G. Rosberg. 1982. "Why Africa's Weak States Persist: The Empirical and the Juridical in Statehood." World Politics 35(1):1-24.

King, Edmund. 1984. “The Anarchy of King Stephen's Reign.” Transactions of the Royal Historical Society 5(34):133-53.

King, Edmund. 1994a. Introduction. In The Anarchy of King Stephen's Reign, ed. Edmund King. Oxford: Clarendon Press pp. 1-36.

King, Edmund, ed. 1994b. The Anarchy of King Stephen's Reign. Oxford: Clarendon Press.

Klare, Michael T. 2004. The Deadly Connection: Paramilitary Bands, Small Arms Diffusion, and State Failure. In When States Fail: Causes and Consequences, ed. Robert I. Rotberg. Princeton, NJ: Princeton University Press pp. 116-134. 
Kreps, David M. 1990. Corporate Culture and Economic Theory. In Perspectives on Positive Political Economy, ed. James E. Alt and Kenneth A. Shepsle. Cambridge: Cambridge University Press pp. 90-143.

Latimer, Paul. 1986. “Grants of 'Totus Comitatus' in Twelfth-Century England: their Origins and Meaning." Bulletin of the Institute of Historical Research 59(140):137-45.

Milgrom, Paul R., Douglass C. North and Barry R. Weingast. 1990. “The Role of Institutions in the Revival of Trade: The Law Merchant, Private Judges, and the Champagne Fairs." Economics and Politics 2:1-23.

Moselle, Boaz and Benjamin Polak. 2001. “A Model of a Predatory State.” Journal of Law, Economics, and Organization 17(1):1-33.

Musah, Abdel-Fatau. 2002. "Privatization of Security, Arms Proliferation and the Process of State Collapse in Africa." Development and Change 33(5):911-33.

Potter, K.R. and R.H.C. Davis, eds. 1976. Gesta Stephani. Oxford: Clarendon Press.

Reno, William. 1997. "War, Markets, and the Reconfiguration of West Africa's Weak States." Comparative Politics 29(4):493-510.

Reno, William. 1998. Warlord Politics and African States. Boulder, CO: Lynne Rienner.

Rotberg, Robert I. 2003. Failed States, Collapsed States, Weak States: Causes and Indicators. In State Failure and State Weakness in a Time of Terror, ed. Robert I. Rotberg. Washington, DC: Brookings Institution Press pp. 1-25.

Scammell, Jean. 1993. "The Formation of the English Social Structure: Freedom, Knights, and Gentry, 1066-1300.” Speculum 68(3):591-618.

Shamma, Jeff S. and Gürdal Arslan. 2005. "Dynamic Fictitious Play, Dynamic Gradient Play, and Distributed Convergence to Nash Equilibria." IEEE Transactions on Automatic Control 50(3):312-27.

Skaperdas, Stergios. 1992. "Cooperation, Conflict, and Power in the Absence of Property Rights." The American Economic Review 82(4):720-739.

Skaperdas, Stergios. 1996. “Contest Success Functions.” Economic Theory 7(1):283-90.

Stenton, Frank. 1961. The First Century of English Feudalism, 1066-1166. 2nd ed. Oxford: Clarendon Press.

Strayer, Joseph R. 1970. On the Medieval Origins of the Modern State. Princeton, NJ: Princeton University Press.

Tullock, Gordon. 1980. Efficient Rent Seeking. In Towards a Theory of the Rent-Seeking Society, ed. James M. Buchanan, Robert D. Tollison and Gordon Tullock. College Station, TX: Texas A\&M University Press pp. 97-112. 
Warren, W.L. 1987. The Governance of Norman and Angevin England, 1086-1272. Stanford, CA: Stanford Univeristy Press.

White, Graeme. 1994. Continuity in Government. In The Anarchy of King Stephen's Reign, ed. Edmund King. Oxford: Clarendon Press pp. 117-143.

Yoshitake, Kenji. 1988a. "The Arrest of the Bishops in 1139 and Its Consequences." Journal of Medieval History 14(2):97-114.

Yoshitake, Kenji. 1988b. "The Exchequer in the Reign of Stephen." English Historical Review 103(409):950-959. 


\begin{tabular}{rrrrrrr}
\hline \hline & & & $\frac{2 \tau}{\frac{1-\delta}{\delta}+p}$ & $\alpha C\left(k_{L}\right)$ & $\frac{2 \tau}{\frac{1-\delta}{\delta}+p}$ & $\alpha C\left(k_{L}\right)$ \\
$k_{L}$ & $\tau$ & $p$ & $\delta=0.9$ & $\alpha=1$ & $\delta=0.6$ & $\alpha=5$ \\
\hline \hline 0 & 1 & 0.0007 & 17.8873 & 0 & 2.9969 & 0 \\
1 & 12 & 0.7946 & 26.4985 & 1 & 16.4241 & 5 \\
2 & 18 & 0.7821 & 40.3040 & 4 & 24.8487 & 20 \\
3 & 22 & 0.7429 & 51.5216 & 9 & 31.2153 & 45 \\
4 & 25 & 0.6992 & 61.7047 & 16 & 36.6068 & 80 \\
5 & 28 & 0.6664 & 72.0247 & 25 & 42.0084 & 125 \\
6 & 31 & 0.6152 & 85.3629 & 36 & 48.3670 & 180 \\
7 & 32 & 0.6047 & 89.4091 & 49 & 50.3395 & 245 \\
8 & 35 & 0.5666 & 103.2888 & 64 & 56.7598 & 320 \\
9 & 38 & 0.5070 & 122.9552 & 81 & 64.7543 & 405 \\
10 & 40 & 0.4884 & 133.4421 & 100 & 69.2601 & 500 \\
11 & 41 & 0.4834 & 137.9285 & 121 & 71.3002 & 605 \\
12 & 42 & 0.4815 & 141.7456 & 144 & 73.1601 & 720 \\
13 & 43 & 0.4361 & 157.1606 & 169 & 77.9857 & 845 \\
14 & 49 & 0.0001 & 881.2069 & 196 & 146.9780 & 980 \\
\hline \hline
\end{tabular}

Table 1. Patron's Decision Problem 


\begin{tabular}{|c|c|c|c|c|}
\hline & County & Earl Existing in 1135 & Created by Stephen & Created by the Empress \\
\hline 1 & Buckingham & Walter Giffard & & \\
\hline 2 & Chester & Ranulf de Gernons & & \\
\hline 3 & Gloucester & Robert son of King Henry & & \\
\hline 4 & Huntingdon & King David of Scotland & & \\
\hline 5 & Leicester & Robert de Beaumont & & \\
\hline 6 & Warwick & Roger de Beaumont & & \\
\hline 7 & Surrey & William de Warenne & & \\
\hline 8 & Northampton & & Simon de Senlis 1136(8) & \\
\hline 9 & Bedford & & Hugh de Beaumont 1137 & \\
\hline 10 & York & & William d'Aumale 1138 & \\
\hline 11 & Derby and Notts & & Robert de Ferrers 1138 & \\
\hline 12 & Pembroke & & Gilbert fitz Gilbert de Clare 1138 & \\
\hline 13 & Hertford & & Gilbert fitz Richard de Clare 1138(41) & \\
\hline 14 & Worcester & & Waleran of Meulan 1138 & \\
\hline 15 & Northumbria & & Henry son of King David 1139 & \\
\hline \multirow[t]{3}{*}{16} & Lincoln & & William d'Aubigny 1139 & \\
\hline & $"$ & & William de Roumare 1140(?) & \\
\hline & ” & & Gilbert de Gant 1149 & \\
\hline 17 & Cambridge & & William de Roumare 1139 & \\
\hline 18 & Sussex & & William d'Aubigny 1140 & \\
\hline 19 & Essex & & Geoffrey de Mandeville 1140 & \\
\hline 20 & Cornwall & & Alan of Brittany 1140 & Reginald fitz Roy 1140 \\
\hline 21 & Wiltshire & & Harvey Brito 1140 & Patrick of Salisbury 1147 \\
\hline 22 & Hereford & & Robert Earl of Leicester 1140 & Miles of Gloucester 1141 \\
\hline 23 & Oxford & & & Aubrey de Vere 1141 \\
\hline 24 & Somerset and Dorset & & & William de Mohun 1141 \\
\hline 25 & Norfolk and Suffolk & & William son of King Stephen 1148(9) & Hugh Bigod 1141 \\
\hline 26 & Devon & & - & Baldwin de Redvers 1141 \\
\hline 27 & Staffordshire & & - & Ranulf Earl of Chester 1153 \\
\hline 28 & Kent & & - & - \\
\hline 29 & Berkshire & & - & - \\
\hline 30 & Hampshire & & - & - \\
\hline 31 & Middlesex & & - & - \\
\hline 32 & Shropshire & & - & - \\
\hline 33 & Richmond & & Alan of Brittany 1136 & - \\
\hline
\end{tabular}

Table 2. Earls and Earldoms ${ }^{10}$

\footnotetext{
${ }^{10}$ Table reproduced from Davis $(1990,130)$
} 
Figure 1: Conflict Game

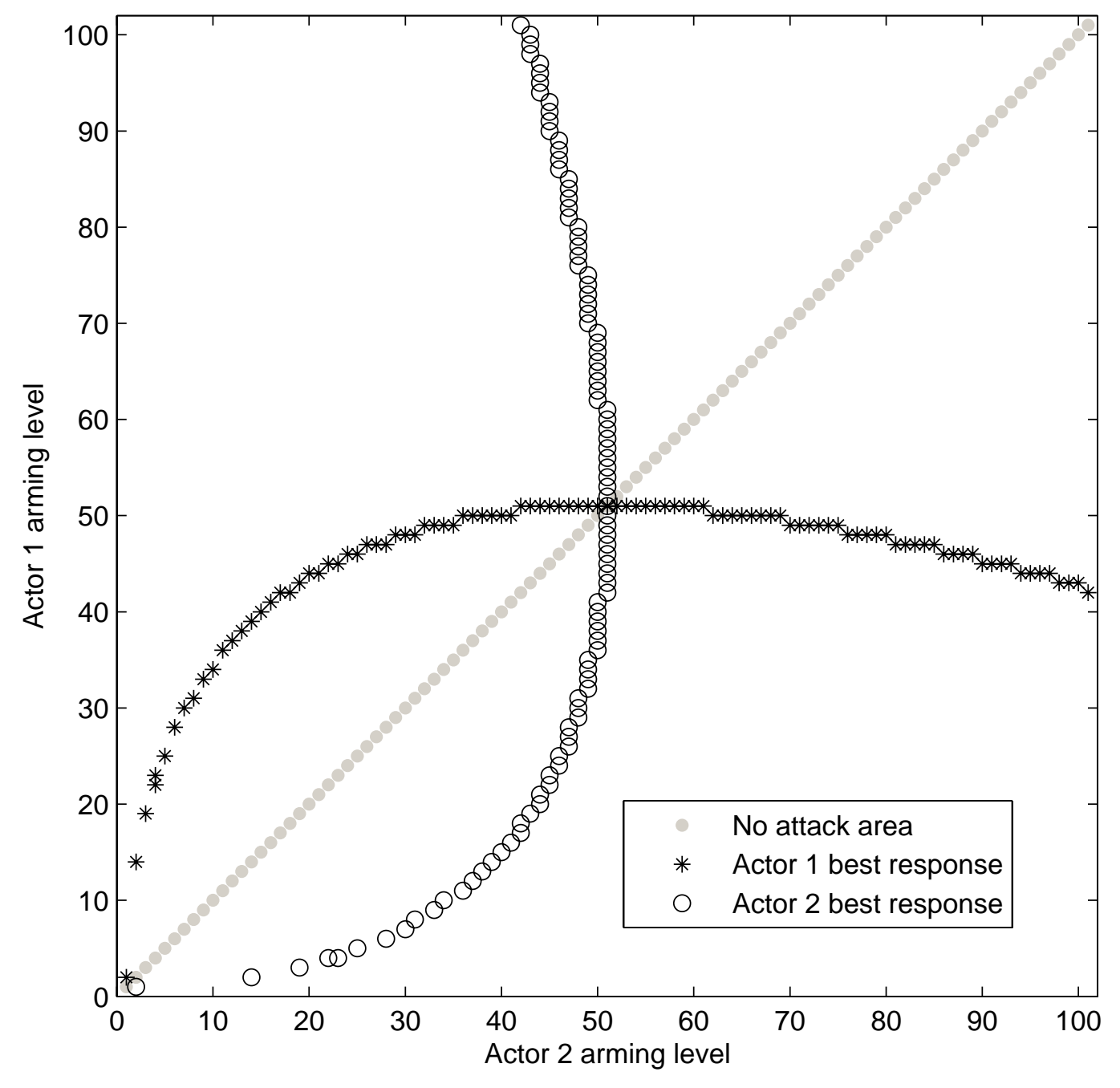


Figure 2. Probability of Conflict

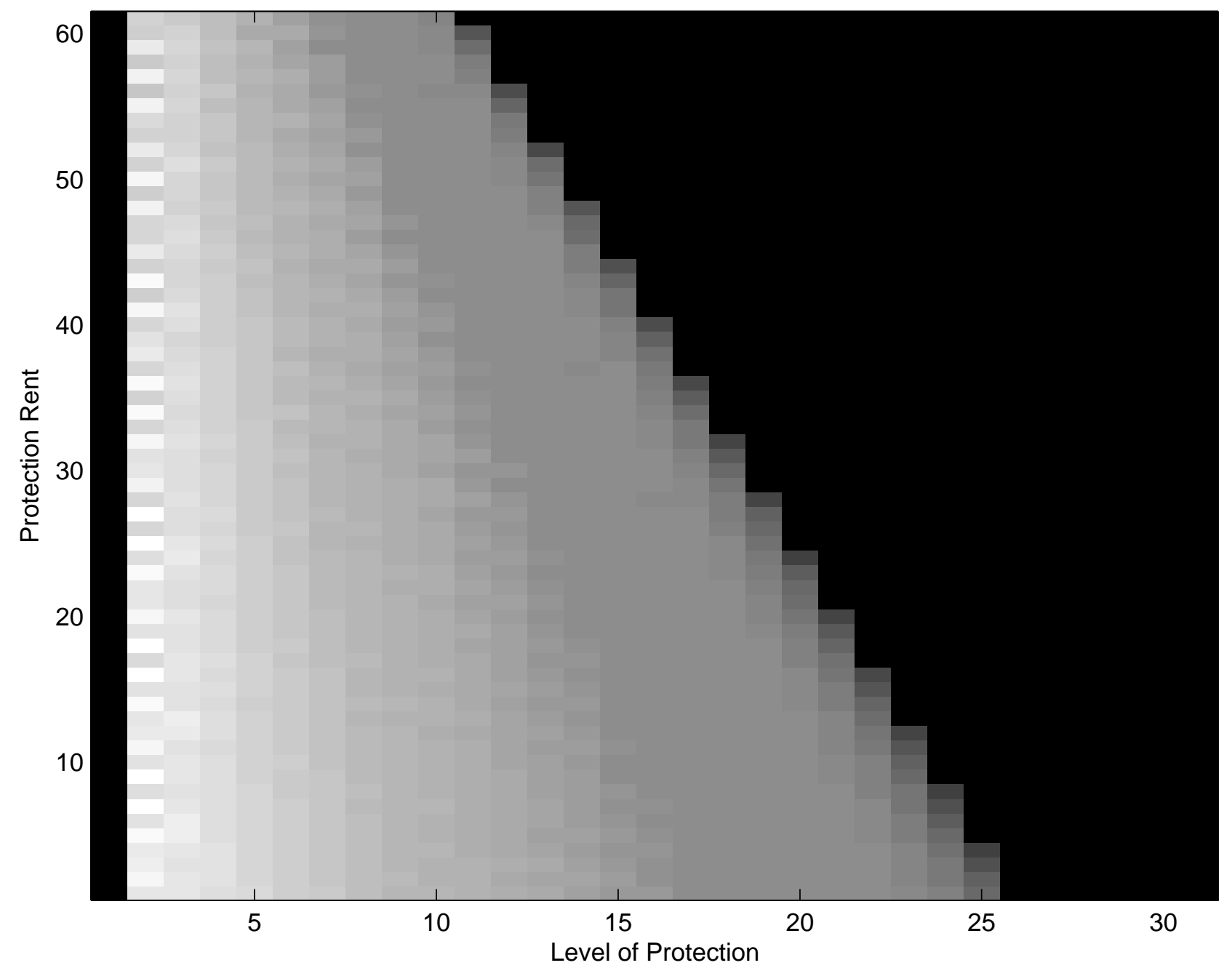


Figure 3: Proprietary-State Game: Two Clients

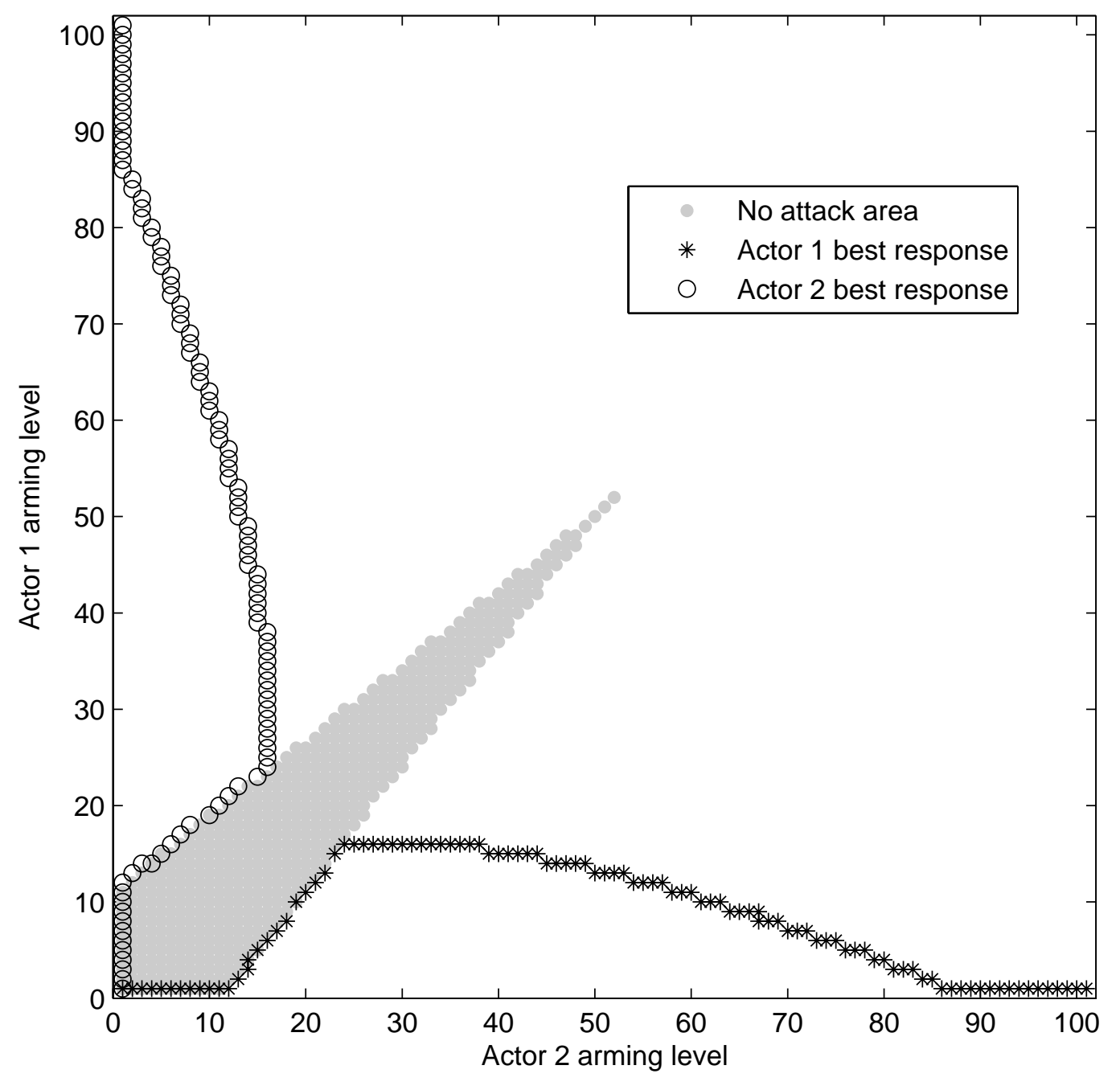


Figure 4: Proprietary-State Game: Weak State

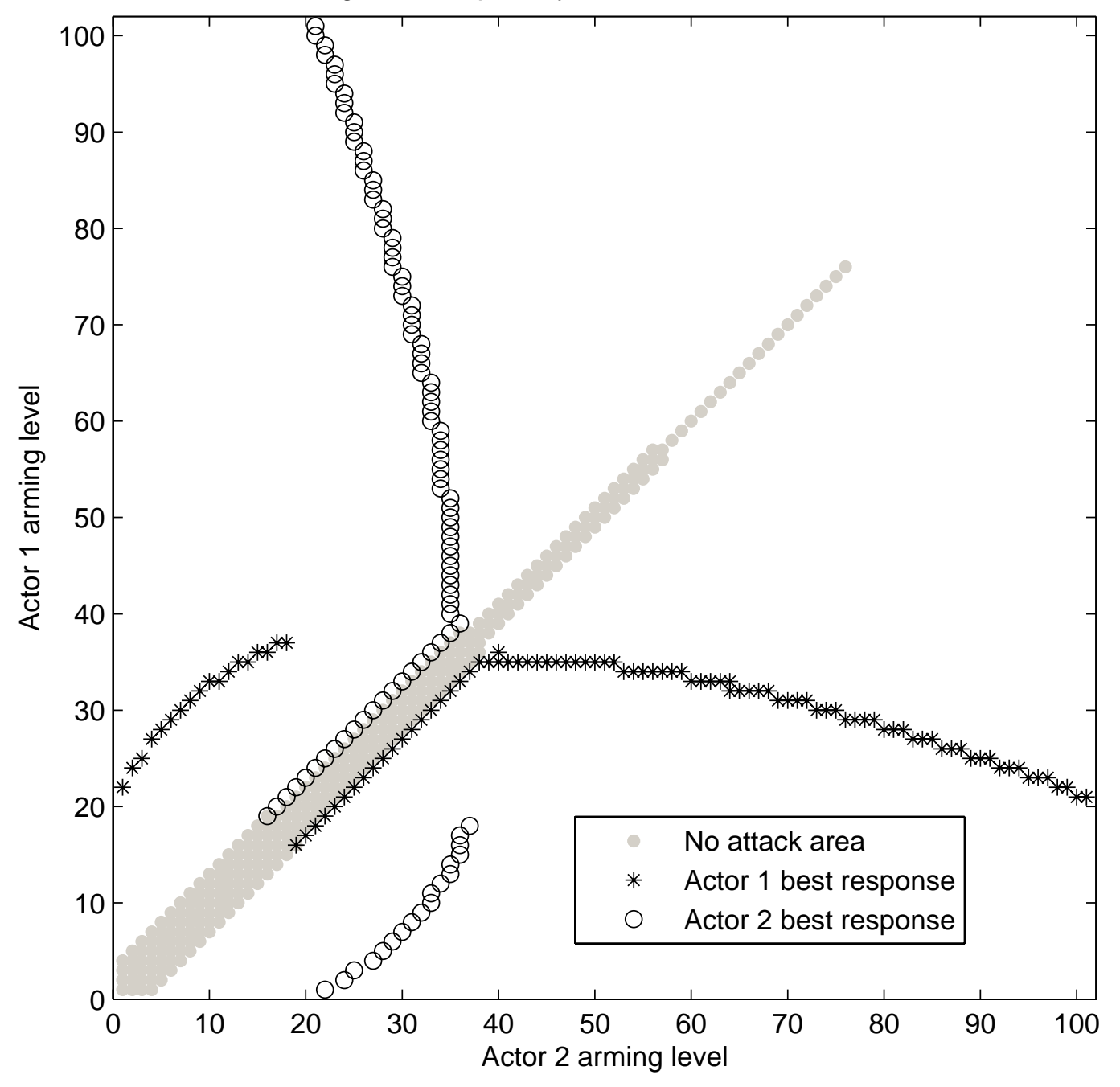


Figure 5. Actors' Decision Problem

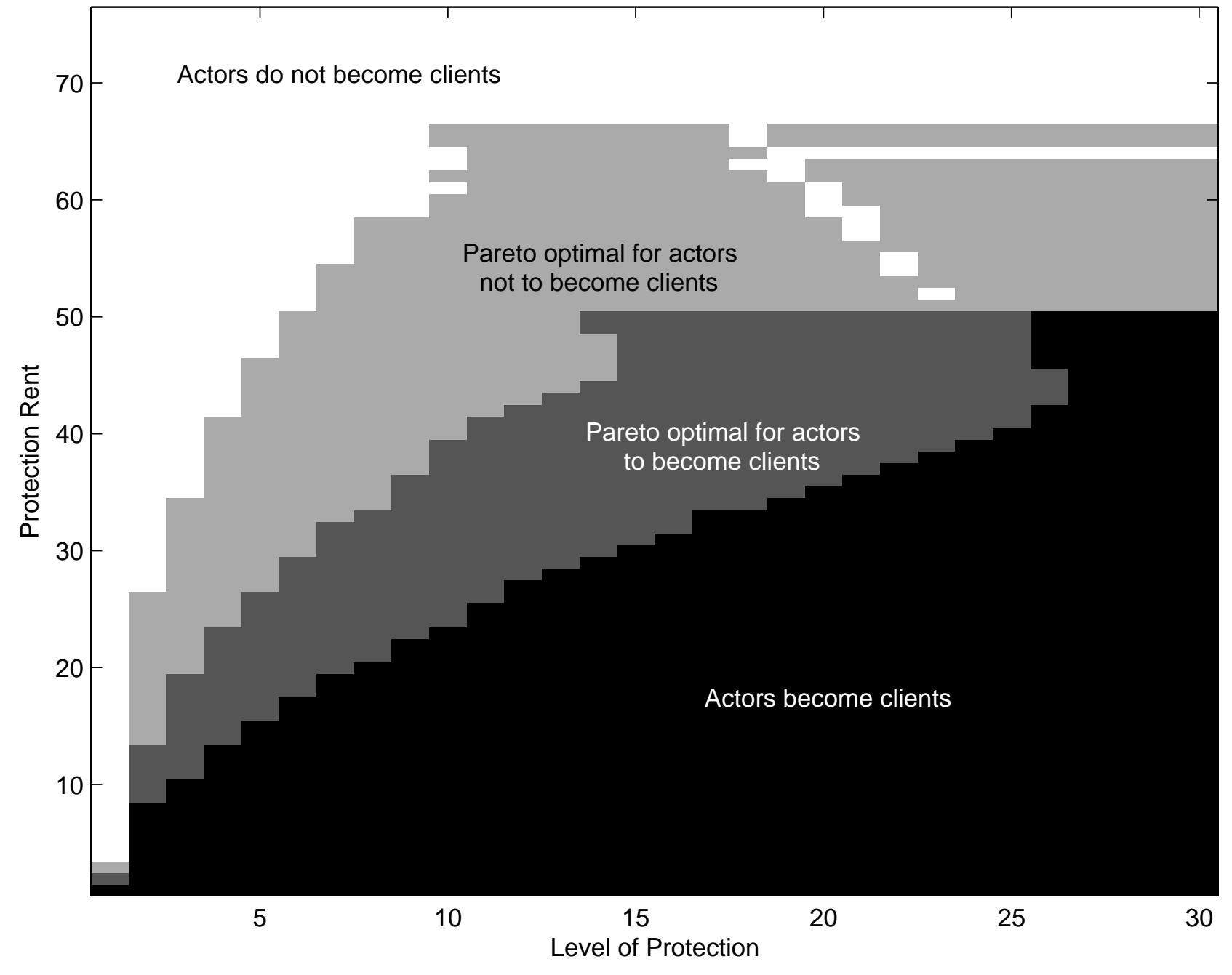

